\title{
ANALISIS FAKTOR-FAKTOR YANG MEMPENGARUHI KONSUMEN DALAM PEMBELIAN TELUR AYAM BURAS DI KELURAHAN TEMBILAHAN KOTA
}

\author{
Bayu Andira Pahlavi ${ }^{1}$, Yeni Afiza ${ }^{2}$ \\ ${ }^{1,2}$ Program Studi Agribisnis Fakultas Pertanian UNISI \\ e-mail :bayu_ap@yahoo.com
}

\begin{abstract}
ABSTRAK
Tujuan penelitian ini adalah : (1) untuk mengetahui faktor-faktor yang mempengaruhi perilaku konsumen dalam pembelian telur ayam buras, (2) untuk mengetahui besarnya pengaruh faktor-faktor tersebut terhadap perilaku konsumen dalam pembelian telur ayam buras di Kelurahan Tembilahan Kota. Hasil penelitian menunjukkan bahwa : (1) variabel yang berpengaruh signifikan terhadap pembelian telur ayam buras adalah usia $(\alpha=10 \%)$, pendapatan $(\alpha=5 \%)$ dan kandungan gizi $(\alpha=$ $10 \%)$, sedangkan variabel yang tidak berpengaruh adalah pendidikan dan harga telur ayam ras, (2) besarnya pengaruh masing-masing variabel ditunjukkan oleh koefesien regresi dengan nilai usia sebesar 0,134 , pendapatan sebesar 1,811 dan kandungan gizi sebesar 1,642.
\end{abstract}

Kata Kunci : Telur Ayam Kampung, Regresi Berganda

\section{ABSTRACT}

The purpose's of the research are: (1) to know what faktors that influence behavior of consumer in indigenous chicken eggs, (2) to know how much the influence of faktors that consumer behavior in indigenous chicken eggs. The result of research showed that: (1) the variable that influence significant are age $(\alpha=10 \%)$, revenue $(\alpha$ $=5 \%)$, and egg nutrition $(\alpha=10 \%)$, while not influence significant are education and price chicken eggs race, (2) the influence of each variable showed with coefficient regression with number size of age 0,134, revenue 1,811 and eggs nutrition 1,642.

Keyword: Indigenous eggs, Multiple Regression

\section{PENDAHULUAN}

Beberapa hewan dapat menghasilkan telur, tetapi hanya jenis telur tertentu yang biasa diperdagangkan dan dikonsumsi manusia yaitu telur ayam, telur bebek, telur itik, telur puyuh dan telur penyu dan telur ikan. Pada kenyataannya telur ayam dan telur bebek yang paling populer di kalangan masyarakat. Ada dua jenis telur ayam yaitu telur ayam kampung (buras) dan telur ayam negeri (ras) (Rasyaf, 2002).

Telur ayam merupakan sumber makan yang bernilai gizi baik. Hampir semua jenis lapisan masyarakat dapat mengkonsumsi telur ayam sebagai 
sumber protein hewani. Hal ini disebabkan telur merupakan salah satu bentuk makanan yang mudah diperoleh, mudah pula cara pengolahannya dan harganya relatif terjangkau. Hal ini menjadikan telur merupakan jenis bahan makanan yang selalu dibutuhkan dan dikonsumsi secara luas oleh masyarakat (Veronika, 2008).

Menurut Badan Pusat Statistik Kabupaten Indragiri Hilir Tahun 2015, produksi telur pada tahun 2013 adalah sebesar $297.973 \mathrm{~kg}$ dan mengalami peningkatan pada tahun 2014 adalah sebesar $436.767 \mathrm{~kg}$. Menurut Sutisna (2001), kebutuhan akan telur berhubungan dengan harga, karena masyarakat dapat menjangkau sesuai dengan pendapatan mereka. Pendapatan yang meningkat sangat berpengaruh terhadap permintaan telur. Apabila pendapatan berubah, maka jumlah permintaan telur pun akan berubah sehingga dapat mempengaruhi kegiatan produksi dan perdagangan telur.

Masyarakat yang semakin maju tingkat pengetahuannya serta semakin meningkatnya pendapatan, semakin sadar akan pentingnya kebutuhan protein dalam kehidupan mereka. Sumber protein dari hewani dapat diperoleh dari ternak salah satunya adalah ayam. Telur ayam buras merupakan salah satu produk hewani dimana nilai gizi yang terkandung didalamnya menyebabkan telur tersebut memiliki kelas dimata masyarakat.

Perilaku konsumen adalah tindakan-tindakan yang dilakukan individu, masyarakat kelompok atau organisasi yang berhubungan dalam proses pengambilan keputusan dalam mendapatkan, menggunakan barangbarang atau jasa ekonomis yang dapat dipengaruhi lingkungan (Mangkunegara, 2002). Perilaku dari kebanyakan konsumen biasanya membeli lebih banyak jika harga barang tersebut turun. Sebagai contoh, harga yang lebih rendah dapat mendorong konsumen yang sudah membeli barang itu untuk membeli dalam jumlah yang lebih besar lagi, dan memungkinkan pembeli lain yang sebelumnya tidak mampu membeli barang tersebut maka akan membeli juga.

Telur ayam buras yang dijual dengan harga yang lebih mahal bila dibandingkan dengan telur ayam ras, cenderung hanya dimanfaatkan untuk memenuhi kebutuhan terbatas, misalnya untuk konsumsi anggota rumah tangga (dalam jumlah yang terbatas), pelengkap minum jamu atau pelengkap acara adat.

Salah satu daerah di Kabupaten Indragiri Hilir yang paling besar mengkonsumsi telur ayam buras adalah Kelurahan Tembilahan Kota, hal ini dikarenakan banyaknya warung kopi ataupun cafe yang menyediakan minuman yang olahannya menggunakan telur ayam buras seperti teh telur, bandrek dan sebagainya. Tujuan penelitian ini adalah 1) untuk mengetahui factor-faktor apa saja yang mempengaruhi perilaku konsumen dalam pembelian telur ayam buras, 2) untuk mengetahui besar pengaruh factor-faktor tersebut terhadap perilaku konsumen dalam pembelian telur ayam buras.

\section{METODOLOGI PENELITIAN}

\subsection{Waktu dan Tempat Penelitian}

Metode penelitian ini menggunakan metode survei, dimana penelitian dilakukan selama tiga bulan, yakni bulan Mei 2016 hingga Juli 2016 di Kelurahan Tembilahan Kota Kecamatan Tembilahan Kabupaten Indragiri Hilir. 


\subsection{Jenis dan Sumber Data}

Data yang dikumpulkan pada penelitian ini meliputi data primer dan data sekunder. Data primer adalah data yang berasal langsung dari sumber data yang dikumpulkan secara khusus dan berhubungan dengan permasalahan yang diteliti. Data primer ini meliputi usia, pendidikan, pendapatan responden dan sebagainya.

Sedangkan data sekunder adalah data yang diperoleh dari laporan suatu lembaga pemerintah maupun swasta yang telah diolah sehingga merupakan data yang sudah jadi. Data sekunder meliputi profil daerah penelitian dan sebagainya.

\subsection{Teknik Pengumpulan Data}

Teknik pengumpulan data dalam penelitian ini adalah survey dengan menggunakan kuesioner atau wawancara langsung dengan para responden yang berdomisili di Kelurahan Tembilahan Kota mengenai masalah yang akan diteliti.

\subsection{Penentuan Sampel}

\begin{tabular}{llr}
\multicolumn{2}{c}{ Teknik pengambilan sampel } \\
dengan menggunakan metode \\
$\begin{array}{lll}\text { accidental } & \text { sampling yaitu setiap } \\
\text { responden yang berdomisili di }\end{array}$
\end{tabular}
Kelurahan Tembilahan Kota yang ditemui dan bersedia dijadikan responden mereka dipersilahkan menjawab daftar pertanyaan yang telah disediakan, dan ditetapkan sebanyak 40 responden yaitu konsumen yang membeli telur ayam kampung. Menurut Uma (2006), ukuran sampel yang tepat adalah lebih dari 30 dan kurang dari 500, jadi 40 adalah lebih dari 30 dan kurang dari 500.

\subsection{Teknik Analisis Data}

Data yang telah terkumpul diolah dengan menggunakan program Microsoft Excel dan SPSS for windows.

\subsubsection{Regresi Linear Berganda}

Analisis data penelitian ini dilakukan dengan menggunakan uji Regresi Linear Berganda. Uji ini digunakan untuk mengetahui pengaruh antara usia, pendidikan, pendapatan, harga dan kandungan gizi terhadap perilaku konsumen dalam pembelian telur ayam kampung. Rumus uji regresi linier berganda sebagai berikut :

$\mathrm{Y}=\alpha+\mathrm{B}_{1} \mathrm{X}_{1}+\mathrm{B}_{2} \mathrm{X}_{2}+\mathrm{B}_{3} \mathrm{X}_{3}+\mathrm{B}_{4} \mathrm{X}_{4}+$ $\mathrm{B}_{5} \mathrm{X}_{5}+\varepsilon$

Keterangan :

Y : Perilaku konsumen dalam pembelian telur ayam buras, (jumlah konsumsi telur dihitung dalam satuan butir/bulan).

$\alpha$ : Konstanta

$\mathrm{X} 1$ : Usia,(tahun)

X2 : Pendidikan (Tahun)

$\mathrm{X} 3$ : Pendapatan per bulan (Rp)

X4 : Harga telur ayam ras, dummy

Tidak berpengaruh : 1

Berpengaruh : 2

Sangat berpengaruh : 3

X5 : Kandungan Gizi, dummy :

Tidak berpengaruh : 1

Berpengaruh : 2

Sangat berpengaruh : 3

$\mathrm{B}_{1}-\mathrm{B}_{5}$ : Koefesien variabel independent

\subsubsection{Uji Hipotesis}

\section{1. $\mathbf{R}^{2}$ (Koefisien Determinan)}

Koefesien determinasi adalah untuk mengetahui seberapa besar persentase sumbangan variabel bebas terhadap variabel terikat yang dapat dinyatakan dalam persentase. Besarnya persentase pengaruh semua variabel independent terhadap nilai variabel dependent dapat diketahui dari besarnya koefisien determinasi $\left(\mathrm{R}^{2}\right)$ persamaan regresi. (Gujarati, 2006). 


\section{Uji F}

Uji F digunakan untuk mengetahui apakah semua variabel independent (X) secara bersama-sama dapat berpengaruh terhadap variabel dependent (Y) (Gujarati, 2006), dengan kriteria:
a. Apabila $F_{\text {hitung }}>F_{\text {tabel }}$ : Signifikan
b. Apabila $F_{\text {hitung }}<F_{\text {tabel }}$ : Tidak Signifikan

\section{Uji t}

Uji $\mathrm{t}$ digunakan untuk mengetahui apakah dalam model regresi, variabel independen $(\mathrm{X})$ secara parsial berpengaruh signifikan terhadap variabel dependen $(\mathrm{Y})$, dengan kriteria:

a. Apabila $t_{\text {hitung }}>t_{\text {tabel }}:$ Signifikan

b. Apabila $t_{\text {hitung }}<t_{\text {tabel }}$ : Tidak Signifikan

\subsubsection{Uji Asumsi Klasik}

\subsubsection{Asumsi Multikolinearitas}

Multikolinearitas merupakan suatu keadaan dimana terjadi satu atau lebih variabel independen yang berkorelasi sempurna atau mendekati sempurna dengan variabel independen lainnya. Asumsi multikolineariti ini menguji apakah dalam model regresi ditemukan adanya korelasi antar variabel independen. Model regresi yang baik seharusnya tidak terjadi korelasi diantara variabel independen. Apabila terjadi multikolineariti maka nilai estimasi parameter menjadi bias. Sehingga akan memberikan hasil verifikasi (pengujian hipotesis) yang tidak berguna bagi pengambilan keputusan (Gujarati, 2006).

Multikolineriti dapat dideteksi dengan melihat besarnya VIF. Apabila VIF > 5 maka dalam model regresi terjadi multikolineariti. Apabila dalam persamaan terjadi multikolineariti, maka langkah yang dilakukan untuk mengatasi multikolineariti yaitu :

- Menambah ukuran sampel/data

- Pemakaian informasi sebelumnya

- Menghilangkan sebuah atau beberapa variabel $\mathrm{X}$

\subsubsection{Asumsi Heterokedastisitas}

Metode OLS baik model regresi sederhana maupun berganda mangasumsikan bahwa variabel gangguan mempunyai rata-rata nol, mempunyai varian yang konstan dan variabel gangguan tidak saling berhubungan antara satu observasi dengan observasi lainnya sehingga menghasilkan estimator OLS yang BLUE. Untuk mengetahui terjadinya heteroskedastisitas dilakukan uji Glejser.

\subsubsection{Asumsi Autokorelasi}

Menurut Ghozali (2005), uji autokorelasi bertujuan menguji apakah dalam model regresi linear ada korelasi antara kesalahan pengganggu pada periode $\mathrm{t}$ dengan kesalahan pengganggu pada periode t-1 (sebelumnya). Jika terjadi korelasi, maka dinamakan ada problem autokorelasi. Model regresi yang baik adalah regresi yang bebas dari autokorelasi dapat dilakukan melalui pengujian terhadap nilai uji Durbin-Watson (Uji DW) dengan ketentuan sebagai berikut :

a) Ada autokorelasi $(0-1,224)$

b) Daerah Keragu-raguan (1,224 $1,553)$

c) Tidak ada Autokorelasi (1,553 2,447)

d) Daerah Keragu-raguan $(2,447 \quad-$ 2,776)

e) Ada Autokorelasi (2,776 - 4)

III. HASIL DAN PEMBAHASAN

3.1 Karakteristik Sampel Penelitian 
Sampel dalam penelitian ini adalah konsumen telur ayam buras yang berada di Kelurahan Tembilahan Kota. Karakteristik konsumen sampel yang dimaksud adalah meliputi karakteristik sosial ekonomi yang terdiri dari umur, tingkat pendidikan dan pendapatan

\subsubsection{Umur}

Tabel 1. Distribusi Konsumen Sampel berdasarkan Kelompok Umur

\begin{tabular}{cccr}
\hline No & Umur (tahun) & Jumlah (orang) & Persentase (\%) \\
\hline 1 & $16-25$ & 3 & 7,50 \\
2 & $26-34$ & 5 & 12,50 \\
3 & $35-44$ & 11 & 27,50 \\
4 & $45-54$ & 14 & 35,00 \\
5 & $55-63$ & 7 & 17,50 \\
\hline \multicolumn{2}{r}{ Jumlah } & 40 & 100,00 \\
\hline
\end{tabular}

Sumber : Data primer diolah, 2016

Tabel 1 diatas dapat dilihat jumlah konsumen sampel yang terbesar berada pada kelompok umur $51-60$ tahun yaitu sebanyak 13 orang atau 32,50 persen, dan yang terkecil berada pada kelompok umur 10 - 20 tahun yaitu sebanyak 2 orang atau 5,00 persen. Menurut Simanjuntak (1996) angkatan kerja dikategorikan produktif apabila umur 15 sampai 54 tahun. Sehingga dapat disimpulkan bahwa konsumen sampel daerah penelitian mayoritas tergolong kedalam usia produktif.
Tingkat pembelian konsumen sangat dipengaruhi oleh usianya, orang akan merubah pola pembeliannya selama umurnya terus bertambah demikian pula pada sampel konsumen telur ayam buras. Adapun keadaan umur konsumen sampel di Kelurahan Tembilahan Kota Kecamatan Tembilahan Kabupaten Indragiri Hilir tersaji pada Tabel 1.

\subsubsection{Pendidikan}

Perilaku konsumen yang satu dengan yang lainnya tidak sama tergantung pada tingkat pendidikannya. Tingkat pendidikan akan mempengaruhi nilai-nilai yang dianutnya, cara berpikir, cara pandang bahkan persepsinya terhadap suatu masalah (Sumarwan, 2003). Adapun tingkat pendidikan konsumen sampel dapat dilihat pada Tabel 2.

Tabel 2. Distribusi Konsumen Sampel berdasarkan Tingkat Pendidikan

\begin{tabular}{clcr}
\hline No & \multicolumn{1}{c}{ Tingkat Pendidikan } & $\begin{array}{c}\text { Jumlah } \\
\text { (orang) }\end{array}$ & $\begin{array}{c}\text { Persentase } \\
(\%)\end{array}$ \\
1 & SD & 2 & 5,00 \\
2 & SLTP & 20 & 50,00 \\
3 & SLTA & 10 & 25,00 \\
4 & SARJANA & 8 & 20,00 \\
\multicolumn{3}{c}{ Jumlah } \\
\multicolumn{2}{c}{ Sumber : Data primer diolah, 2016 }
\end{tabular}


Dari Tabel 2 diatas dapat dilihat bahwa tingkat pendidikan konsumen sampel yang paling banyak adalah pada tingkat SLTP yaitu sebanyak 20 orang atau sebesar 50,00 persen.

\subsubsection{Pendapatan}

Menurut Pusparini (2013), pendapatan merupakan imbalan yang diterima oleh seseorang dari pekerjaan yang dilakukannya untuk mencari nafkah. Penghasilan pada umumnya dalam bentuk uang. Jumlah penghasilan akan menggambarkan daya beli seseorang, yang selanjutnya akan mempengaruhi pola konsumsinya. Komposisi pendapatan responden dapat dilihat pada Tabel 3.

Tabel 3. Komposisi Pendapatan Rata-rata Keluarga per Bulan

\begin{tabular}{clcr}
\hline No & \multicolumn{1}{c}{ Pendapatan } & Jumlah (Orang) & Persentase (\%) \\
\hline 1 & < Rp.2.000.000 & 13 & 32,50 \\
2 & Rp.2.000.000-Rp.4.000.000 & 25 & 62,50 \\
3 & $>$ Rp. 4.000.000 & 2 & 5,00 \\
\hline & Jumlah & 40 & 100,00 \\
\hline
\end{tabular}

Sumber : Data primer diolah, 2016

Dari Tabel 3 diatas dapat dilihat bahwa pendapatan rata-rata konsumen sampel terbesar pada kelompok $\mathrm{Rp}$. 2.000.000 - Rp. 4.000.000/bulan yaitu sebanyak 25orang atau sebesar 62,50 persen dan yang terkecil pada kelompok $>$ Rp. 4.000.000/bulan yaitu sebanyak 2 orang atau sebesar 5 persen. Sehingga dapat disimpulkan bahwa pendapatan konsumen sampel di daerah penelitian bervariasi.

\subsection{Faktor-faktor yang Mempengaruhi Konsumen dalam Pembelian Telur Ayam Buras}

Hasil analisis regresi linear berganda menunjukkan ada 3 faktor yang mempengaruhi konsumen dalam pembelian telur ayam kampung yaitu usia, pendapatan dan kandungan gizi. Faktor-faktor tersebut tersaji pada Tabel 4.

Tabel 4. Hasil Pengolahan Regresi Linear Berganda

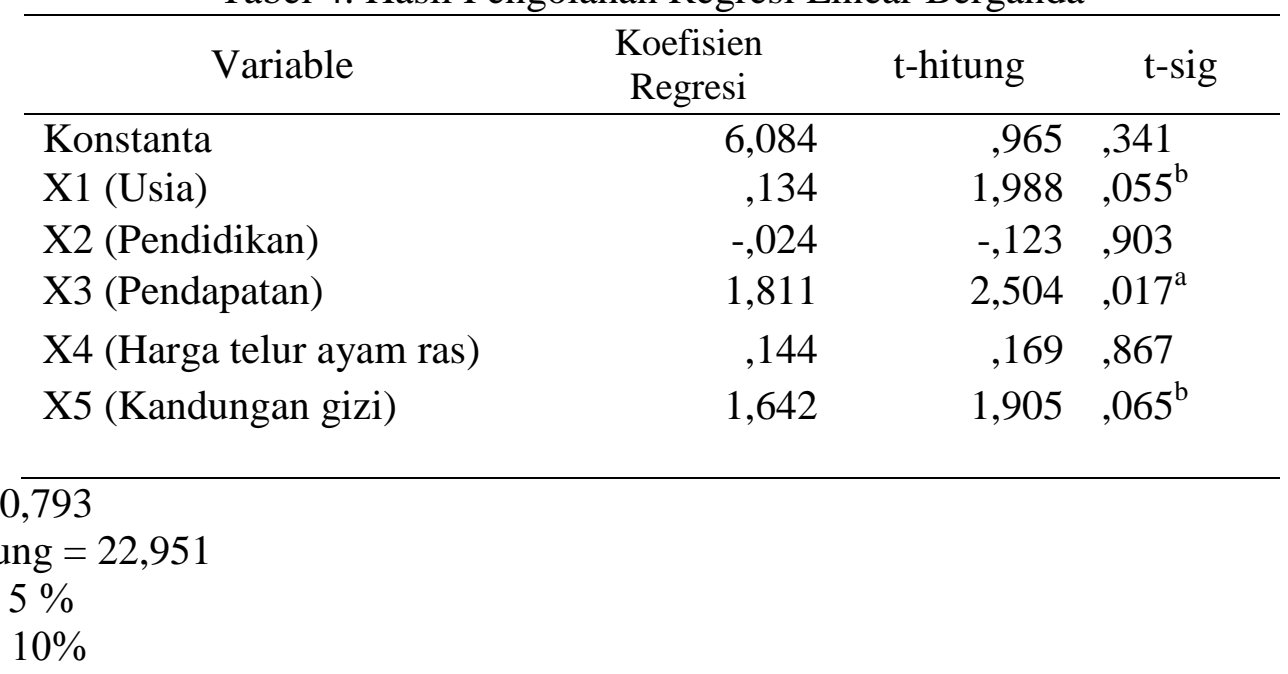

Berdasarkan tabel 4, maka persamaan regresi linear bergandanya adalah : 
$Y=6,084+0,134 X_{1}-0,024 X_{2}+1,811 X_{3}+0,144 X_{4}+1,642 X_{5}$

\subsubsection{Pengujian Model}

\section{Koefisien Determinasi $\left(\mathrm{R}^{2)}\right.$}

Nilai koefesien determinasi $\left(\mathrm{R}^{2}\right)$ yang diperoleh sebesar 0,793 yang berarti bahwa model regresi yang diperoleh dapat menjelaskan keragaman variabel terikat (pembelian telur ayam buras) sebesar 79,3\%, sedangkan sisanya $20,7 \%$ diterangkan oleh variabel lain yang tidak termasuk dalam model ini, misalnya rasa, selera, dan lain-lain. 2. Uji F

\begin{tabular}{rrrr}
\multicolumn{2}{c}{ Berdasarkan hasil analisis } \\
regresi & diketahui bahwa & secara \\
serempak & faktor-faktor & yang
\end{tabular} mempengaruhi pembelian telur ayam buras (usia, pendidikan, pendapatan, harga telur ayam ras dan kandungan gizi) memberikan pengaruh nyata terhadap pembelian telur ayam buras. Hal ini disimpulkan berdasarkan nilai $F$ hitung sebesar 22,951 sedangkan F tabel $(0,05)$ adalah sebesar 2,37. Dalam pengambilan keputusan diketahui bahwa apabila F-hitung > F-tabel berarti ada pengaruh nyata variabel usia, pendidikan, pendapatan, harga telur ayam ras dan kandungan gizi terhadap pembelian telur ayam buras.

3. Uji t

Dari hasil analisis regresi dapat juga dilihat bahwa secara parsial faktorfaktor yang mempengaruhi pembelian telur ayam buras, penjelasannya adalah sebagai berikut :

a. Secara parsial nilai t-hitung variabel usia adalah 1,988 lebih besar dari nilai t-tabel 1,30 artinya variabel usia signifikan pada taraf kepercayaan $90 \%(\alpha=10 \%)$.

b. Pada variabel pendidikan nilai thitung -0,123, artinya variabel pendidikan tidak signifikan $(\alpha=$ 90\%).

c. Nilai t-hitung variabel pendapatan adalah 2,504 lebih besar dari nilai ttabel 1,30, artinya variabel pendapatan signifikan pada taraf kepercayaan 95\% $(\alpha=5 \%)$.

d. Untuk variabel harga telur ayam ras nilai t-hitung 0,169 , artinya variabel harga telur ayam ras tidak signifikan $(\alpha=90 \%)$.

e. Nilai t-hitung variabel kandungan gizi adalah 1,905 lebih besar dari nilai t-tabel 1,69, artinya variabel kandungan gizi signifikan pada taraf kepercayaan $90 \%(\alpha=10 \%)$.

\subsubsection{Uji Asumsi Klasik}

1. Multikolonearitas

Asumsi multikolineariti ini menguji apakah dalam model regresi ditemukan adanya korelasi antar variabel independen. Model regresi yang baik seharusnya tidak terjadi korelasi diantara variabel independen. Apabila terjadi multikolineariti maka nilai estimasi parameter menjadi bias. Sehingga akan memberikan hasil verifikasi (pengujian hipotesis) yang tidak berguna bagi pengambilan keputusan (Gujarati, 2006). Hasil uji multikolonearitas dapat dilihat pada Tabel 5.

Tabel 5. Hasil Uji Multikolonearitas

\begin{tabular}{lr}
\hline \multicolumn{1}{c}{ Variable } & \multicolumn{1}{c}{ VIF } \\
\hline X1 (Usia) & 1,057 \\
X2 (Pendidikan) & 1,086 \\
X3 (Pendapatan) & 1,304 \\
\hline
\end{tabular}




\begin{tabular}{cc}
\hline X4 (Harga telur ayam ras) & 1,190 \\
X5 (Kandungan gizi) & 1,110 \\
\hline Sumber : Data primer diolah, 2016 &
\end{tabular}

Tabel 5 memperlihatkan bahwa semua variabel tidak terjadi multikolonearitas dengan nilai VIF < 10. Menurut Gujarati (2000), regresi yang baik seharusnya tidak terjadi korelasi diantara variabel independen.

\section{Heterokedastisitas}

Metode OLS baik model regresi sederhana maupun berganda mangasumsikan bahwa variabel gangguan mempunyai rata-rata nol, mempunyai varian yang konstan dan variabel gangguan tidak saling berhubungan antara satu observasi dengan observasi lainnya sehingga menghasilkan estimator OLS yang BLUE (Gujarati, 2000). Untuk mengetahui terjadinya heterokedastisitas dilakukan dengan uji Glejser. Hasil pengujian dapat dilihat pada Tabel 6.

Tabel 6. Hasil Uji Heterokedastisitas

\begin{tabular}{|c|c|c|}
\hline No & Variabel & Signifikansi \\
\hline 1 & X1 (Usia) & 1,294 \\
\hline 2 & X2 (Pendidikan) & 1,219 \\
\hline 3 & X3 (Pendapatan) & 1,360 \\
\hline 4 & X4 (Harga telur ayam ras) & 1,315 \\
\hline 5 & X5 (Kandungan gizi) & 1,131 \\
\hline
\end{tabular}

Sumber : Data primer diolah, 2016

Berdasarkan Tabel 6 dapat dilihat bahwa semua variabel tidak terjadi heterokedastisitas. Hal ini dapat dibuktikan dengan diperolehnya nilai signifikansi untuk masing-masing variabel yang lebih besar dari 5\% (sig > $0,05)$.

\section{Autokorelasi}

Menurut Ghozali (2005), uji autokorelasi bertujuan menguji apakah dalam model regresi linear ada korelasi antara kesalahan pengganggu pada periode $\mathrm{t}$ dengan kesalahan pengganggu pada periode t-1 (sebelumnya). Jika terjadi korelasi, maka dinamakan ada problem autokorelasi.

Hasil penelitian diperoleh nilai DW sebesar 1,777. Sehingga dapat disimpulkan bahwa model regresi tidak terjadi autokorelasi. Menurut Ghozali (2005), model regresi yang baik adalah regresi yang bebas dari autokorelasi dapat dilakukan melalui pengujian terhadap nilai uji Durbin-Watson (Uji DW) dengan ketentuan sebagai berikut :

a) Ada autokorelasi $(0-1,224)$

b) Daerah Keragu-raguan (1,224 $1,553)$

c) Tidak ada Autokorelasi (1,553 2,447)

d) Daerah Keragu-raguan $(2,447 \quad$ 2,776)

e) Ada Autokorelasi (2,776 - 4)

\subsubsection{Pengaruh Setiap Variabel Terhadap Pembelian Telur}

1. Variabel usia berpengaruh positif dan signifikan terhadap pembelian telur ayam buras dengan koefesien regresi 0,055 yang artinya setiap penambahan umur satu tahun maka pembelian telur ayam buras akan semakin meningkat sebesar 0,055 butir. Umur konsumen merupakan salah satu faktor pribadi yang 
memiliki kaitan erat dengan cara pandang dan cara berpikir dalam menentukan suatu keputusan. Umur konsumen dianggap penting karena konsumen yang berbeda umur akan mengkonsumsi barang yang berbeda. Dari hasil penelitian umur konsumen sampel bervariasi dari umur yang muda sampai yang tua dengan jumlah konsumsi telur ayam buras yang berbeda pula. Menurut Pusparini (2013), konsumen yang berbeda umur akan mengkonsumsi barang yang berbeda. Konsumen melakukan pembelian sepanjang hidupnya dan setiap tahapan kehidupan dari mulai kecil hingga dewasa akan membeli barang yang berbeda sesuai dengan adanya perbedaan kebutuhan.

2. Variabel pendidikan berpengaruh positif dan signifikan terhadap pembelian telur ayam buras dengan koefesien regresi 0,291 yang artinya setiap peningkatan tingkat pendidikan maka pembelian telur ayam buras akan semakin meningkat sebesar 0,291 butir. Semakin tinggi tingkat pendidikan konsumen maka akan semakin tinggi pula pengetahuan konsumen akan kandungan gizi yang terdapat pada telur ayam buras. Menurut Veronika (2008), tingkat pendidikan menggambarkan perubahan dalam tingkah laku individual yang muncul dari pengalaman. Tingkat pendidikan formal yang dimiliki konsumen akan menunjukkan tingkat pengetahuan serta wawasan dalam mengambil keputusan

3. Harga telur ayam ras berpengaruh positif dan signifikan terhadap pembelian telur ayam buras dengan koefesien regresi 1,298 yang artinya semakin tinggi harga telur ayam ras maka semakin meningkat pula pembelian telur ayam buras. Hal ini dikarenakan kandungan gizi yang terdapat pada telur ayam buras lebih tinggi dibandingkan dengan telur ayam ras. Kebanyakan konsumen membeli telur ayam buras dalam bentuk hasil olahan seperti salah satu campuran jamu, kemudian telur ayam buras juga sering dijadikan obat tradisional. Hal ini senada dengan penelitian yang dilakukan Veronika (2008), bahwa harga telur ayam lain berpengaruh nyata terhadap permintaan konsumen telur ayam kampung.

Sedangkan variabel yang tidak signifikan adalah variabel pendapatan dan variabel kandungan gizi. Hal ini dikarenakan berdasarkan hasil penelitian mayoritas yang banyak mengkonsumsi telur ayam buras adalah responden yang sudah berumur dan memiliki pekerjaan yang membutuhkan tenaga. Sedangkan responden yang memiliki pendidikan yang lebih tinggi jarang mengkonsumsi telur ayam buras. Sehingga walaupun harga telur ayam buras lebih mahal dibandingkan telur ayam ras, tetapi responden tetap membelinya karena telur ayam buras dikonsumsi sebagai penambah energi bagi tubuh.

\section{KESIMPULAN DAN SARAN}

\subsection{Kesimpulan}

1. Variabel yang berpengaruh signifikan dalam pembelian telur ayam buras adalah usia ( $\alpha=10 \%$ ), pendapatan $(\alpha=5 \%)$ dan kandungan gizi $(\alpha=10 \%)$, sedangkan variabel yang tidak berpengaruh signifikan adalah pendidikan dan harga telur ayam ras.

2. Besarnya pengaruh masing-masing variabel adalah sebagai berikut :

a. Variabel usia dengan koefesien regresi 0,134 yang artinya setiap penambahan umur satu tahun 
maka pembelian telur ayam buras akan semakin meningkat sebesar 0,134 butir.

b. Variabel pendapatan dengan koefesien regresi 1,811 yang artinya setiap peningkatan pendapatan satu juta maka pembelian telur ayam buras akan semakin meningkat sebesar 1,811 butir.

c. Variabel kandungan gizi berpengaruh signifikan, yang artinya makin meningkatnya kandungan gizi telur ayam buras maka akan semakin meningkat pula pembelian telur ayam buras.

\subsection{Saran}

1. Sebaiknya pedagang melihat kesempatan untuk memasarkan telur ayam buras dari faktor-faktor yang mempengaruhi perilaku konsumen.

2. Kepada peternak diharapkan dapat meningkatkan kualitas dan kuantitas produk telur ayam buras karena kebutuhan masyarakat yang terus meningkat karena manfaat yang terkandung didalamnya.

\section{DAFTAR PUSTAKA}

Agus,dkk. 2002.Ayam Kampung Petelur.AgroMedia Pustaka. Jakarta.

Assael. Henry. 2001.Consumer Behaviour. New York : Thomson-Learning.

Gilarso. T. 1993. Pengantar Ilmu Ekonomi.Kanisius. Yogyakarta.

Ghozali Imam. 2011. Aplikasi Analisis Multivariate dengan Program IBM SPSS19. Badan Penerbit
Universitas

Diponegoro.

Semarang.

Gujarati. 2006. Dasar-dasar Ekonometrika. Penerbit Erlangga. Jakarta.

Kotler. Philip. 2008. Manajemen Pemasaran.Edisi Milennium diterjemahkan Benyamin Molan. PT.Prenhallindo. Jakarta.

Kotler. Philip dan Armstrong (1996). Prinsip-prinsip Pemasaran. Jilid I. Erlangga. Jakarta.

Ma'rifa. N.S.dkk. 2013.Analisis Penawaran dan Permintaan Telur Ayam Ras di Sumatera Utara.Jurnal. Fakultas Pertanian Universitas Sumatera Utara. Medan.

Mosher. A.T. 1996. Menggerakkan dan Membangun Pertanian.CV.Yasa Guna. Jakarta.

Pusparini. dkk. 2013.Perilaku Konsumen dalam Pembelian Telur Ayam Kampung di Malang (Studi Kasus Wilayah Pedesaan dan Perkotaan).Jurnal. Fakultas Peternakan Universitas Brawijaya. Malang.

Putong, Iskandar. 2013. Economics : Pengantar Mikro dan Makro. Mitra Wacana Media. Jakarta.

Rasyaf. M. 2002.Beternak Ayam Petelur.Penebar Swadaya.Jakarta.

Schiffman. L.G. dan Kanuk. L.L. 2008. Consumer

Behavior.Pearson Prentice Hall. New Jersey. 
Simanjuntak PJ. 1996. Pengantar

Ekonomi Sumber Daya

Manusia. Fakultas Ekonomi.

Universitas Indonesia. Jakarta.

Soediyono.S.B. 1981.Perilaku Harga Pasar dan Konsumen.Liberty. Yogyakarta.

Sumarwan.V. 2003. Perilaku Konsumen Teori dan Penerapannya dalam Pemasaran.Ghalia Indonesia. Jakarta.

Sutisna. 2001.Perilaku Konsumen dan Komunikasi Pemasaran.PT.Remaja Rosdakarta. Bandung.
Umar. H. 2000. Riset Pemasaran dan Perilaku Konsumen.Gramedia Pustaka Utama dan JBRC. Jakarta.

Uma Sekaran. 2006. Research Methods Business, Edisi 4, Buku 1. Salemba Empat. Jakarta

Veronika. H. S. 2008. Faktor-faktor Yang Mempengaruhi Perilaku Konsumen Terhadap Permintaan Telur Ayam Kampung (Studi kasus: Kota Medan, Propinsi Sumatera Utara).Skripsi. Universitas Sumatera Utara. Medan. 